\title{
Penerapan Metode Association Rule Untuk Menganalisa Pola Pemakaian Bahan Kimia Di Laboratorium Menggunakan Algoritma FP-Growth (Studi Kasus di Laboratorium Kimia PT. PLN (Persero) Sektor Pembangkitan Belawan Medan)
}

\author{
Buyung Solihin Hasugian \\ Universitas Dharmawangsa Medan \\ Jl. Kl. Yos Sudarso No. 224 Medan Sumatera Utara \\ Email : buyung@dharmawangsa.ac.id
}

\begin{abstract}
ABSTRAK
Pola pemakaian bahan kimia di laboratorium PT. PLN (Persero) Sektor Pembangkitan Belawan Medan tidak hanya untuk mengetahui bahan kimia apa saja yang terpakai namun juga dapat mengetahui jumlah bahan kimia yang tersisa sehingga pihak petugas laboratorium dapat mengelola pemakaian bahan kimia tersebut dengan baik. Salah satu cara yang tepat dalam penentuan pola pemakaian bahan kimia tersebut adalah dengan menggunakan teknik data mining. Adapun teknik Data Mining yang digunakan dalam hal ini adalah Algoritma FP-Growth. FP-Growth merupakan salah satu alternatif algoritma yang dapat digunakan untuk penentuan himpunan data yang paling sering muncul (frequent item set) dalam sebuah kumpulan data. Penelitian dilakukan dengan menggunakan beberapa variabel yaitu tanggal dan bahan kimia yang dipakai. Hasil dari penelitian ini berupa suatu pola pemakaian bahan kimia dimana diproses dengan menggunakan perangkat lunak yaitu mengimplementasikan algoritma FP-Growth dengan menggunakan konsep pembangunan FP-Tree dalam mencari Frequent Itemset.
\end{abstract}

Kata Kunci : Data Mining, Association Rules, Frequent Itemset, FP-Growth.

\section{ABSTRACT}

The pattern of using chemicals in the laboratory of PT. PLN (Persero) Sektor Pembangkitan Belawan Medan is not only to find out what chemicals are used but also to find out the amount of chemicals left so that laboratory officials can properly manage the use of these chemicals. One appropriate way to determine the pattern of use of these chemicals is to use data mining techniques. The Data Mining technique used in this case is the FP-Growth Algorithm. FP-Growth is an alternative algorithm that can be used to determine the most frequent set of data in a data set. The study was conducted using several variables, namely the date and chemicals used. The results of this study are in the form of a chemical usage pattern which is processed using software, namely implementing the FPGrowth algorithm using the concept of FP-Tree development in searching for Frequent Itemset.

Keywords: Data Mining, Association Rules, Frequent Itemset, FP-Growth 


\section{PENDAHULUAN}

Laboratorium kimia merupakan tempat menganalisa dan mengolah berbagai jenis bahan kimia yang dinilai sangat penting untuk diperhatikan, mengingat besarnya dampak kerugian yang disebabkan oleh berbagai kesalahan yang akan terjadi apabila kondisi ataupun penggunaan bahan kimia di laboratorium digunakan secara sembarangan. Penggunaan bahan kimia memiliki berbagai ketentuan dan syarat-syarat khusus demi menjaga dan menghindari berbagai hal yang tidak dinginkan. Dalam hal ini salah satu teknik yang dapat digunakan yaitu penerapan Data Mining. Teknik Data Mining yang akan digunakan dalam penelitian ini adalah Association Rule.

Adapun dalam penelitian ini akan dibahas bagaimana cara mengimplementasikan salah satu algoritma dalam data mining, yaitu algoritma FP-Growth. Algoritma ini adalah bagian dari teknik asosiasi pada data mining. Adapun FP-Growth sendiri adalah salah satu altenatif algoritma yang dapat digunakan untuk menentukan himpunan data yang paling sering mucul (frequent itemset) dalam sekumpulan data. Karakteristik algoritma FP-Growth adalah struktur data yang digunakan dalam tree yang disebut FP-Tree.

\section{LITERATUR}

\subsection{Knowledge Discovery in Databases (KDD)}

Knowledge Discovery in Databases (KDD) adalah penerapan metode saintifik pada Data Mining. Dalam konteks ini, Data Mining merupakan satu langkah dari proses KDD (Hermawati, 2009)

\subsection{Data Mining}

Data Mining adalah proses yang mempekerjakan satu atau lebih teknik pembelajaran komputer (machine learning) untuk menganalisis dan mengekstraksi pengetahuan (knowledge) secara otomatis (Hermawati, 2009).

\subsection{Association Rules}

Association Rule merapakan tugas data mining yang mendasar (L.Bing,2007).Menurut "Data Preparationfor Data Mining" dalam Applied Artificial Intelligence (Zhang, Zhang,\& Yang, 2003) Association Rule merupakan salah satu metode yang bertujuan untuk mencari pola yang sering muncul pada banyak transaksi, dimana setiap transaksi terdiri dari beberapa item (Rama 2014).

\subsection{Algoritma FP-Growth}

Ririanti, (2014), menyatakan FP-Growth adalah salah satu alternatif algoritma yang dapat digunakan untuk menentukan himpunan data yang paling sering muncul (frequent item set) dalam sekumpulan data. Algoritma FP-Growth merupakan pengembangan dari algoritma Apriori.

\section{METODE PENELITIAN}

Dalam penelitian ini penulis melakukan beberapa mekanisme yaitu Mekanisme pertama adalah teoritis, di mana penulis mengutip dari buku, jurnal, atau literatur yang berhubungan dengan objek yang penulis teliti. Mekanisme kedua adalah praktis, di mana penulis melakukan analisa dan perancangan serta menguji dengan menggunakan aplikas Rapidminer 5.3. Untuk menerangkan kedua mekanisme tersebut penulis merangkum dalam kerangka kerja penelitan. 


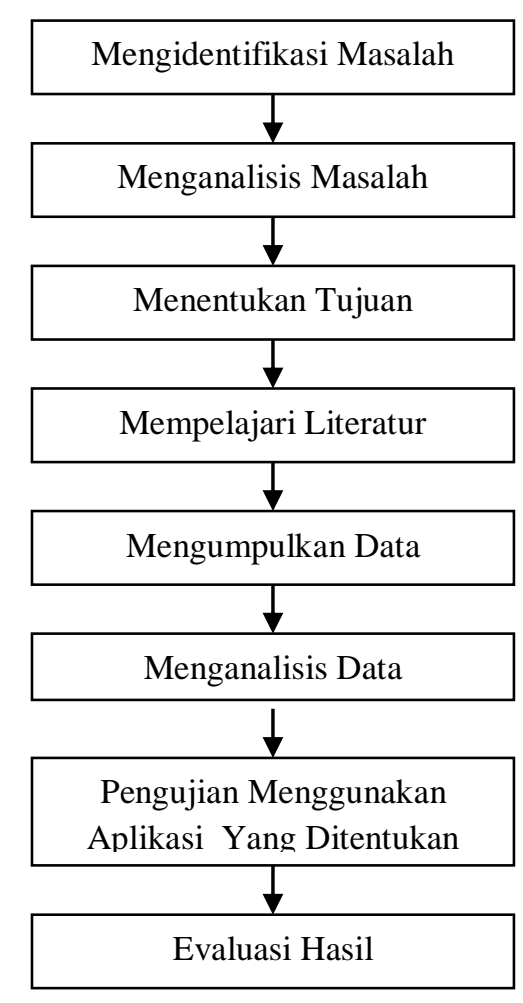

Gambar 1 Kerangka Kerja Penelitian

Diharapkan agar masalah yang telah dianalisis dapat dipahami dengan baik.

\section{Menentukan Tujuan}

Tujuan dari penelitian ini adalah :

a. Menganalisa pola pemakaian bahan kimia yang dilakukan secara berkesinambungan di laboratorium kimia PT. PLN (Persero) Sektor Pembangkitan Belawan Medan.

b. Menerapkan informasi yang dihasilkan dari proses penggalian data pemakaian bahan kimia di laboratorium kimia PT. PLN (Persero) Sektor Pembangkitan Belawan Medan guna menunjang kinerja perusahaan.

c. Membangun sebuah sistem agar pamakaian bahan kimia dapat terkontrol dengan baik.

\section{Mempelajari Literatur}

Literatur-literatur yang dipakai sebagai bahan referensi dalam penelitian ini adalah dari jurnal-jurnal ilmiah, modul pembelajaran dan buku tentang Data Mining. literatur-literatur ini akan menjadi pedoman untuk melakukan penelitian agar memudahkan proses penelitian. Dalam prosesnya diperlukan literatur yang berguna untuk pemahaman konsep dan pendalaman teori tentang Data Mining untuk Menentukan Pola Pemakaian Bahan Kimia Di Laboratorium Menggunakan Algoritma Fp-Growth dari beberapa sumber jurnal nasional, internasioanl, buku-buku dan internet. 


\section{Mengumpukan data}

Dalam penelitian ini teknik pengumpulan data yang dilakukan adalah penelitian dengan cara melakukan pengamatan langsung ke lokasi laboratorium kimia PT. PLN (Persero) Sektor Pembangkitan Belawan Medan. Selain pengamatan, juga dilakukan wawancara kepada pihak-pihak yang terkait dengan penelitian ini. Di samping itu juga, melakukan pengambilan sampel data bahan kimia untuk menunjang penelitian ini.

\section{Menganalisis Data}

Pada tahap ini data yang telah dikumpulkan kemudian dianalisis. Analisis dengan menggunakan Association Rule dilakukan melalui penghitungan support dan confidence dari suatu hubungan item.

Tahapan dalam menganalisis data yang dilakukan sebagai berikut :

a. Menganalisa pola frequent item pada data pemakaian bahan kimia dengan menentukan nilai minimum support.

b. Setelah semua pola frequent item ditemukan, kemudian dicari aturan assosiatif yang memenuhi syarat minimum confidence .

c. Menemukan pola association rule dengan menggunakan pendekatan algoritma FP-Growth.

d. Melakukan proses Generate Rule menggunakan algoritma FP-Growth Dengan melakukan pembentukan FP-Tree sehingga proses ekstraksi frequent item dapat dilakukan secara lebih mudah.

\section{Pengujian Menggunakan Aplikasi Yang Telah Ditentukan}

Pada tahap ini, rule diuji menggunakan sistem Data Mining yang sudah ada. Tools yang digunakan sebagai pengujian sistem adalah Rapidminer 5.3. Tahapan-tahapan dalam proses pengujian dengan menggunakan Rapidminer 5.3 adalah sebagai berikut:

a. Data pemakaian bahan kimia yang sudah ada sebelumnya di transformasikan ke dalam Microsoft Excel.

b. Mengimport data pemakaian bahan kimia yang akan dijadikan sebagai data tabel transaksi frequent itemset di dalam tools Rapidminer 5.3

c. Melakukan proses Input Data dan association rule untuk menemukan aturan asosiasi antara suatu kombinasi item

d. Menentukan minimum support dan

confidence

e. Memperoleh informasi baru yaitu berupa aturan-aturan asosiasi pola pemakaian bahan kimia

\section{Evaluasi Hasil}

Setelah pengujian data dilakukan, hasil analisis dengan cara manual dan pengujian dengan menggunakan tools yaitu Rapidminer 5.3 akan terlihat perbandingannya. Setelah memperoleh informasi berupa pola asosiasi dengan menggunakan algoritma FP-Growth pada data pemakaian bahan kimia yang telah dianalisa, maka dapat diambil berbagai kesimpulan yang nantinya dapat dijadikan sebagai acuan dalam melakukan berbagai kegiatan yang terkait dengan pemakaian bahan kimia guna menjaga, mempermudah ataupun meningkatkan kinerja perusahaan. 


\section{Hasil Dan Pembahasan}

Pemakaian bahan kimia pada laboratorium kima PT. PLN (Persero) Sektor Pembangkitan Belawan Medan dilakukan secara rutin. Pemakaian bahan kimia yang dilakukan secara rutin tentunya memiliki pola asosiasi antara satu item dengan item lainya. Adapun data sampel pemakaian bahan kimia yang dilakukan pada periode Januari 2015 adalah sebagai berikut :

Tabel 1 Pemakaian Bahan Kimia Bulan Januari 2015

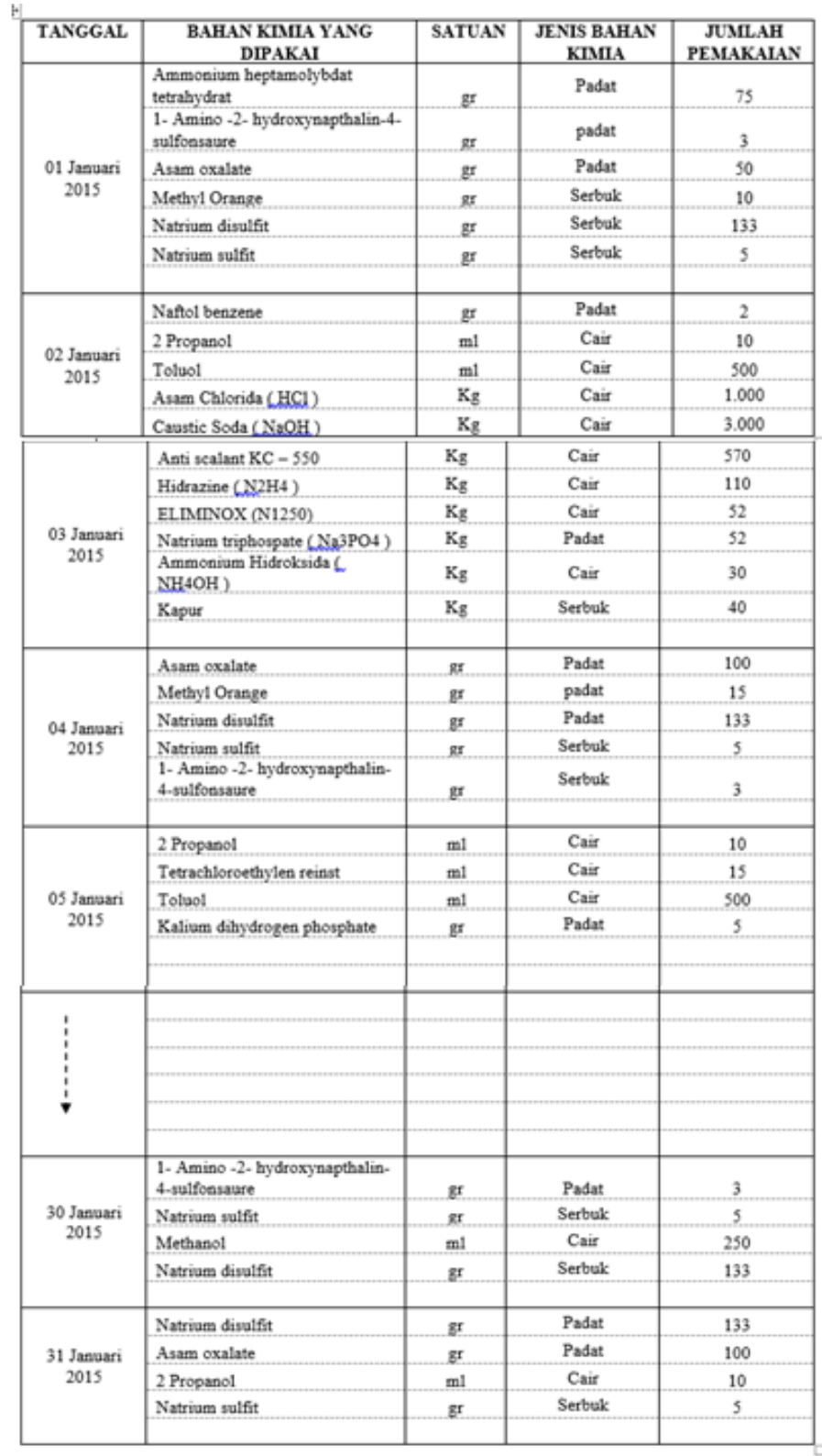

Setelah memperoleh data transaksi pemakaian bahan kimia yang telah diuraikan pada Tabel di atas, maka selanjutnya dilakukan penambahan initial seperti pada tabel dibawah ini : 
Tabel 2 Pemberian Initial Pada Setiap Itemset

\begin{tabular}{|l|l|}
\hline \multicolumn{1}{|c|}{ Nama Bahan Kimia } & \multicolumn{1}{c|}{ Initial } \\
\hline Ammonium heptamolybdat tetrahydrat & A \\
\hline 1- Amino -2- hydroxynapthalin-4-sulfonsaure & B \\
\hline Asam oxalate & C \\
\hline Methyl Orange & D \\
\hline Natrium disulfit & E \\
\hline Natrium sulfit & F \\
\hline Naftol benzene & G \\
\hline Propanol & H \\
\hline Toluol & I \\
\hline Asam Chlorida (HCl) & J \\
\hline Caustic Soda (NaOH) & K \\
\hline Anti scalant KC - 550 & L \\
\hline Hidrazine (N2H4) & M \\
\hline ELIMINOX (N1250) & N \\
\hline Natrium triphospate (Na3304) & 0 \\
\hline Ammonium Hidroksida(NH40H) & P \\
\hline Kapur & Q \\
\hline Methanol & R \\
\hline Tetrachloroethylen reinst & S \\
\hline Kalium dihydrogen phosphate & T \\
\hline
\end{tabular}

Setelah memberikan initial pada setiap data transaksi pemakaian bahan kimia, seperti pada Tabel 2 maka dapat dilakukan analisa pola asosiasi dengan menggunakan algoritma FP-Growth dengan menentukan minimum support sebesar $20 \%$ dan minimum Confidence sebesar $50 \%$.

Penggalian itemset yang frequent dengan menggunakan algoritma FP-Growth akan dilakukan dengan cara membangkitkan struktur data tree atau disebut dengan FP-Tree. Metode FP-Growth dapat dibagi menjadi 3 tahapan utama yaitu :

1. Tahap pembangkitan conditional pattern base

2. Tahap pembangkitan conditional FP-Tree

3. Tahap pencarian frequent itemset.

\section{Tahap pembangkitan Conditional pattern base}

Dari data transaksi pemakaian bahan kimia yang tertera pada tabel 1 di atas, maka dapat dilakukan pembangkitan conditional pattern base dengan melakukan pemilihan variabel dari hasil penentuan initial dari setiap item yang tertera pada tabel 2. Pemilihan variabel dilakukan 
ALGORITMA: Jurnal Ilmu Komputer dan Informatika

Volume: 03, Number: 02, November 2019 ISSN 2598-6341 (online)

berdasarkan variabel yang dianggap penting, variabel yang digunakan adalah Tanggal dan Bahan Kimia Yang Digunakan. Maka data transaksi pemakaian bahan kimia yang akan dianalisa akan dijelaskan pada tabel 3 sebagai berikut :

Tabel 3 Data Transaksi Dengan Variabel Terpilih

\begin{tabular}{|c|c|c|}
\hline TID & TANGGAL & BAHAN KIMIA YANG DIPAKAI \\
\hline 1 & 01 Januari 2015 & $\mathrm{~A}, \mathrm{~B}, \mathrm{C}, \mathrm{D}, \mathrm{E}, \mathrm{F}$ \\
\hline 2 & 02 Januari 2015 & G. H. I, J, K \\
\hline 3 & 03 Januari 2015 & L M N O P, Q \\
\hline 4 & 04 Januari 2015 & B, C, D, E, F \\
\hline 5 & 05 Januari 2015 & H, I, S, T \\
\hline 6 & 06 Januari 2015 & $\mathrm{~B}, \mathrm{E}, \mathrm{F}, \mathrm{J}$ \\
\hline 7 & 07 Januari 2015 & C, D, E \\
\hline 8 & 08 Januari 2015 & B, I, J, K, \\
\hline 9 & 09 Januari 2015 & H, I, S, T \\
\hline 10 & 10 Januari 2015 & $\mathrm{I}, \mathrm{M}, \mathrm{N}, \mathrm{O}$ \\
\hline 11 & 11 Januari 2015 & B, C, E, F, J \\
\hline 12 & 12 Januari 2015 & I, M, P, R \\
\hline 13 & 13 Januari 2015 & A. B.E. F \\
\hline 14 & 14 Januari 2015 & C, D, E, F \\
\hline 15 & 15 Januari 2015 & B, E, F \\
\hline 16 & 16 Januari 2015 & I, R, S, T \\
\hline 17 & 17 Januari 2015 & $\mathrm{M}, \mathrm{O}, \mathrm{P}$ \\
\hline 18 & 18 Januari 2015 & B, C, F \\
\hline 19 & 19 Januari 2015 & C, I, P, R \\
\hline 20 & 20 Januari 2015 & $\mathrm{C}, \mathrm{N}, \mathrm{O}$ \\
\hline 21 & 21 Januari 2015 & C, D, I, P \\
\hline 22 & 22 Januari 2015 & $\mathrm{H}, \mathrm{J}, \mathrm{K}, \mathrm{R}$ \\
\hline 23 & 23 Januari 2015 & D, I, P, S \\
\hline 24 & 24 Januari 2015 & B, C.E.F \\
\hline 25 & 25 Januari 2015 & $\mathrm{D}, \mathrm{L}, \mathrm{M}, \mathrm{N}, \mathrm{S}$ \\
\hline 26 & 26 Januari 2015 & C, I, P, R \\
\hline 27 & 27 Januari 2015 & C, F, P \\
\hline 28 & 28 Januari 2015 & C, D, I \\
\hline 29 & 29 Januari 2015 & D, F,M \\
\hline 30 & 30 Januari 2015 & B, E, F, R \\
\hline 31 & 31 Januari 2015 & C, E, F, H \\
\hline
\end{tabular}

Berdasarkan data pemakaian bahan kimia di atas, terlihat bahwa setiap transaksi yang ada terdapat lebih dari 1 item bahan kimia yang digunakan, oleh karena itu data tersebut dapat langsung digunakan untuk melakukan perhitungan frequent item seperti terdapat pada tabel berikut :

Tabel 4 Frequent Items

\begin{tabular}{|c|c|c|c|}
\hline Items & Frequent & \multicolumn{2}{|c|}{ Support } \\
\hline Ammonium heptamolybdat tetrahydrat (A) & 2 & $2 / 31 \times 100 \%$ & $6,45 \%$ \\
\hline 1- Amino -2- hydroxynapthalin-4-sulfonsaure (B) & 10 & $10 / 31 \times 100 \%$ & $32,25 \%$ \\
\hline Asam oxalate (C) & 14 & $14 / 31 \times 100 \%$ & $45,16 \%$ \\
\hline Methyl Orange (D) & 9 & $9 / 31 \times 100 \%$ & $29,03 \%$ \\
\hline Natrium disulfit (E) & 11 & $11 / 31 \times 100 \%$ & $35,48 \%$ \\
\hline Natrium sulfit (F) & 13 & $13 / 31 \times 100 \%$ & $41,94 \%$ \\
\hline Naftol benzene (G) & 1 & $1 / 31 \times 100 \%$ & $3,23 \%$ \\
\hline 2 Propanol $(\mathrm{H})$ & 5 & $5 / 31 \times 100 \%$ & $16,12 \%$ \\
\hline Toluol (I) & 12 & $12 / 31 \times 100 \%$ & $38,71 \%$ \\
\hline Asam Chlorida (HCl) (J) & 5 & $5 / 31 \times 100 \%$ & $16,12 \%$ \\
\hline Caustic Soda $(\mathrm{NaOH})(\mathrm{K})$ & 3 & $3 / 31 \times 100 \%$ & $9,68 \%$ \\
\hline Anti scalant $\mathrm{KC}-550(\mathrm{~L})$ & 2 & $2331 \times 100 \%$ & $6,45 \%$ \\
\hline Hidrazine $(\mathrm{N} 2 \mathrm{H} 4)(\mathrm{M})$ & 6 & $6 / 31 \times 100 \%$ & $19,35 \%$ \\
\hline ELIMINOX $(\mathrm{N} 1250)(\mathrm{N})$ & 4 & $4 / 31 \times 100 \%$ & $12,90 \%$ \\
\hline Natrium triphospate $(\mathrm{Na} 3 \mathrm{PO} 4)(\mathrm{O})$ & 4 & $4 / 31 \times 100 \%$ & $12,90 \%$ \\
\hline Ammonium Hidroksida $(\mathrm{NH} 4 \mathrm{OH})(\mathrm{P})$ & 8 & $8 / 31 \times 100 \%$ & $25,81 \%$ \\
\hline Kapur (Q) & 1 & $1 / 31 \times 100 \%$ & $3,22 \%$ \\
\hline Methanol (R) & 6 & $6 / 31 \times 100 \%$ & $19,35 \%$ \\
\hline Tetrachloroethylen reinst (S) & 5 & $5 / 31 \times 100 \%$ & $16,13 \%$ \\
\hline Kalium dihydrogen phosphate $(T)$ & 3 & $3 / 31 \times 100 \%$ & $9,68 \%$ \\
\hline
\end{tabular}


ALGORITMA: Jurnal Ilmu Komputer dan Informatika

Volume: 03, Number: 02, November 2019 ISSN 2598-6341 (online)

Setelah mendapatkan nilai minimum frequent items, maka dilakukan penyaringan data dengan nilai minimum frequent items sebesar $30 \%$. Dengan demikian, itemset yang memiliki nilai minimum frequent items $30 \%$ yaitu : items $C$, F, I, E, dan B. Jadi selain 5 item yang dicari dengan menentukan minimum support tersebut tidak digunakan untuk membangun FP-Tree. Hasil penyaringan data transaksi pemakaian bahan kimia yang telah dilakukan dapat dilihat pada tabel 5 di bawah ini :

Tabel 5 Data Items Dengan Nilai Minimum Frequent Item 30\%

\begin{tabular}{|l|c|c|c|}
\hline \multicolumn{1}{|c|}{ Items } & Frequent & \multicolumn{2}{c|}{ Support } \\
\hline 1- Amino -2- hydroxynapthalin-4-sulfonsaure (B) & 10 & $10 / 31 \times 100 \%$ & $32,25 \%$ \\
\hline Asam oxalate (C) & 14 & $14 / 31 \times 100 \%$ & $45,16 \%$ \\
\hline Natrium disulfit (E) & 11 & $11 / 31 \times 100 \%$ & $35,48 \%$ \\
\hline Natrium sulfit (F) & 13 & $13 / 31 \times 100 \%$ & $41,94 \%$ \\
\hline Toluol (I) & 12 & $12 / 31 \times 100 \%$ & $38,71 \%$ \\
\hline
\end{tabular}

Setelah mendapatkan items dengan minimum support 30\% maka data transaksi pemakaian bahan kimia yang akan dianalisa dapat dilihat pada tabel 4.6 :

Tabel 6 Data Items Dengan Nilai Minimum Frequent Item 30\%

\begin{tabular}{|c|c|c|}
\hline TID & TANGGAL & BAHAN KIMLA YANG DIPAKAI \\
\hline 1 & 01 Januari 2015 & C, F, E, B \\
\hline 2 & 02 Januari 2015 & I \\
\hline 3 & 03 Januari 2015 & - \\
\hline 4 & 04 Januari 2015 & C, F, E, B \\
\hline 5 & 05 Januari 2015 & I \\
\hline 6 & 06 Januari 2015 & F, E, B \\
\hline 7 & 07 Januari 2015 & C, E \\
\hline 8 & 08 Januari 2015 & I, B \\
\hline 9 & 09 Januari 2015 & I \\
\hline 10 & 10 Januari 2015 & I \\
\hline 11 & 11 Januari 2015 & C, F, E, B \\
\hline 12 & 12 Januari 2015 & I \\
\hline 13 & 13 Januari 2015 & F, E, B \\
\hline 14 & 14 Januari 2015 & C, F, E \\
\hline 15 & 15 Januari 2015 & F, E, B \\
\hline 16 & 16 Januari 2015 & I \\
\hline 17 & 17 Januari 2015 & - \\
\hline 18 & 18 Januari 2015 & $\mathrm{C}, \mathrm{F}, \mathrm{B}$ \\
\hline 19 & 19 Januari 2015 & C. I \\
\hline 20 & 20 Januari 2015 & $\mathbf{C}$ \\
\hline 21 & 21 Januari 2015 & $\mathrm{C}, \mathrm{I}$ \\
\hline 22 & 22 Januari 2015 & - \\
\hline 23 & 23 Januari 2015 & I \\
\hline 24 & 24 Januari 2015 & C, F, E, B \\
\hline 25 & 25 Januari 2015 & - \\
\hline 26 & 26 Januari 2015 & C. I \\
\hline 27 & 27 Januari 2015 & C, F \\
\hline 28 & 28 Januari 2015 & C, I \\
\hline 29 & 29 Januari 2015 & F \\
\hline 30 & 30 Januari 2015 & F, E, B \\
\hline 31 & 31 Januari 2015 & C, F, E \\
\hline
\end{tabular}




\section{Tahap pembangkitan conditional FP-Tree}

Maka langkah selanjutnya adalah membentuk pohon FP-Tree dengan melihat tabel 4.6. Gambar di bawah ini memberikan ilustrasi mengenai pembentukan FP-tree setelah pembacaan TID pada tabel 6 .

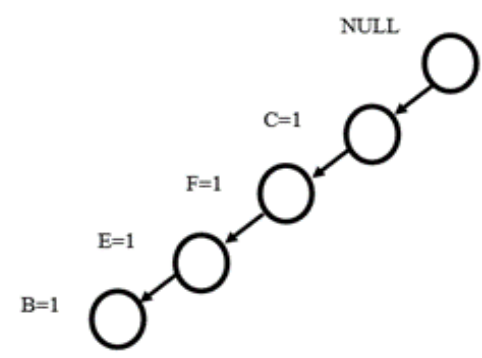

Gambar. 2 Pembentukan FP-Tree setelah melakukan pembacaan TID 1

Gambar. 2 Pembentukan FP-Tree setelah pembacaan didapat setelah melakukan TID 1, Yaitu berisi : NULL- C (Asam oxalate) $=1, \mathrm{~F}$ (Natrium sulfit) =1, E (Natrium disulfit) =1, B (1- Amino -2hydroxynapthalin-4-sulfonsaure $)=1$.

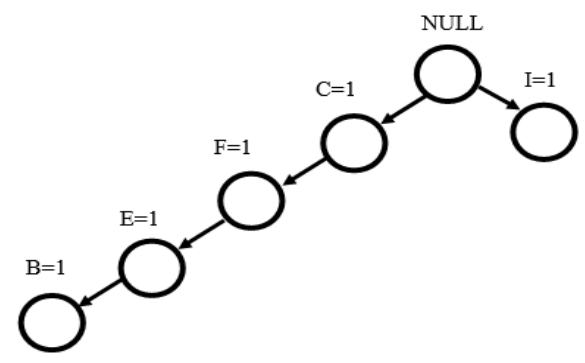

\section{Gambar. 3 Pembentukan FP-Tree setelah melakukan pembacaan TID 2}

Gambar 3 didapat setelah melakukan TID 2 ,Yaitu: NULL-I (Toluol) =1.

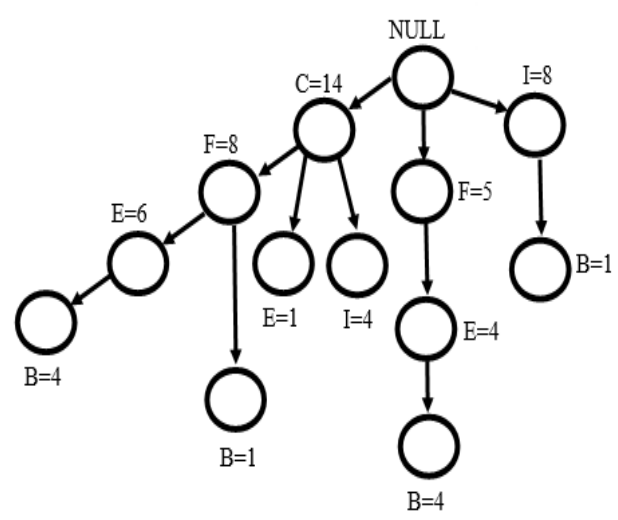

Gambar. 4 Pembentukan FP-Tree setelah melakukan pembacaan TID 31 
Gambar. 4 Pembentukan FP-Tree didapat setelah melakukan pembacaan pada TID 31 yaitu berisi : NULL $-\mathrm{C}($ Asam oxalate $)=14, \mathrm{~F}($ Natrium sulfit $)=8, \mathrm{E}($ Natrium disulfit $)=6$.

Untuk menemukan Frequent itemset dari tabel 4.5, maka terlebih dahulu ditentukan lintasan yang berakhir dengan support count terkecil, yaitu lintasan B, E, yang diikuti dengan I, F, dan di akhiri C. Proses pembentukan masing-masing node dapat dilihat pada gambar 2 sampai 4 :

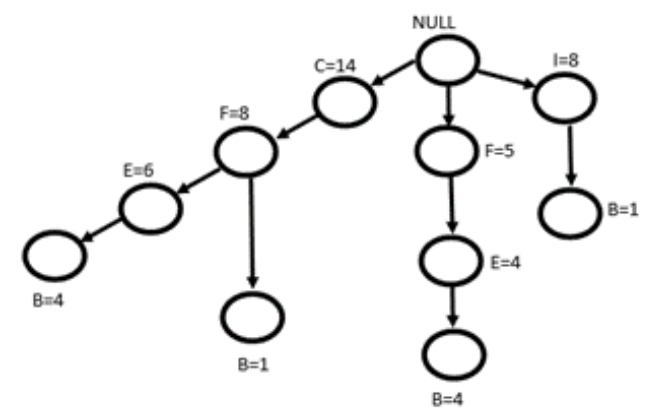

Gambar 5 Lintasan yang Mengandung Simpul B

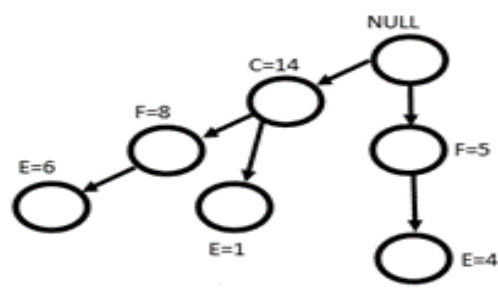

Gambar 6 Lintasan yang Mengandung Simpul E<smiles>C1CCCCC1</smiles>

Gambar 7 Lintasan yang Mengandung Simpul C

Tabel 7 Daftar Frequent Itemset Diurutkan Berdasarkan Hubungan Akhiran

\begin{tabular}{|c|c|}
\hline Suffix & Frequent Itemset \\
\hline B & $\{\mathrm{B}\}_{\infty}\{\mathrm{II}, \mathrm{B}\},\{\mathrm{F}, \mathrm{E}, \mathrm{B}\},\{\mathrm{C}, \mathrm{F}, \mathrm{B}\},\{\mathrm{C}, \mathrm{F}, \mathrm{E}, \mathrm{B}\}$ \\
\hline E & $\left\{\mathrm{E}_{2}\left\{\mathrm{~F}_{2} \mathrm{E}\right\},\{\mathrm{C}, \mathrm{E}\},\{\mathrm{C}, \mathrm{F}, \mathrm{E}\}\right.$ \\
\hline I & $\{\mathrm{I}\},\{\mathrm{LBR}\},\{\mathrm{C}, \mathrm{I}\}$ \\
\hline $\mathrm{F}$ & $\left\{\mathrm{F}_{2}\{\mathrm{~S}, \mathrm{~F}\}\right.$ \\
\hline $\mathrm{C}$ & $\{C\}$ \\
\hline
\end{tabular}

\section{Tahap Pencarian Frequent Itemset}

Pencarian Association Rules dilakukan melalui dua tahap yaitu pencarian frequent itemset dan penyusutan rules. Support adalah ukuran yang menunjukan tingkat dominasi itemset dari kesuluruhan transaksi. 
ALGORITMA: Jurnal Ilmu Komputer dan Informatika

Volume: 03, Number: 02, November 2019 ISSN 2598-6341 (online)

Tabel 8 Frequent Itemset Dengan Nilai Minimum Support 20\%

\begin{tabular}{|c|c|c|c|}
\hline No & Itemset & Jumlah & \multicolumn{1}{c|}{ Support } \\
\hline 1 & C,F & 8 & $8 / 31 \times 100 \%=25,81 \%$ \\
\hline 2 & F,C & 8 & $8 / 31 \times 100 \%=25,81 \%$ \\
\hline 3 & C,E & 7 & $7 / 31 \times 100 \%=22,58 \%$ \\
\hline 4 & E,C & 7 & $7 / 31 \times 100 \%=22,58 \%$ \\
\hline 5 & F,E & 10 & $10 / 31 \times 100 \%=32,26 \%$ \\
\hline 6 & E,F & 10 & $10 / 31 \times 100 \%=32,26 \%$ \\
\hline 7 & F, B & 9 & $9 / 31 \times 100 \%=29,03 \%$ \\
\hline 8 & B,F & 9 & $9 / 31 \times 100 \%=29,03 \%$ \\
\hline 9 & B,E & 8 & $8 / 31 \times 100 \%=25,81 \%$ \\
\hline 10 & E,B & 8 & $8 / 31 \times 100 \%=25,81 \%$ \\
\hline 11 & F,E, B & 8 & $8 / 31 \times 100 \%=25,81 \%$ \\
\hline 12 & F,B,E & 8 & $8 / 31 \times 100 \%=25,81 \%$ \\
\hline 13 & E,B,F & 8 & $8 / 31 \times 100 \%=25,81 \%$ \\
\hline 14 & E,F,B & 8 & $8 / 31 \times 100 \%=25,81 \%$ \\
\hline 15 & F, E,B & 8 & $8 / 31 \times 100 \%=25,81 \%$ \\
\hline 16 & B,F,E & 8 & $8 / 31 \times 100 \%=25,81 \%$ \\
\hline
\end{tabular}

Parameter lainnya adalah confidence yaitu nilai ukuran seberapa besar valid tidaknya suatu Association Rules. Sebuah Association Rules dengan confidence sama atau lebih besar dari minimum confidence dapat dikatakan sebagai valid association rule. Setelah mendapatkan nilai support, maka dilakukan perhitungan nilai confidence sebagai berikut :

Tabel 9 Frequent Itemset Minimum Support dan Confidence

\begin{tabular}{|c|c|c|c|l|}
\hline No & Itemset & Jumlah & Support $\%$ & \multicolumn{1}{|c|}{ Confidence $\%$} \\
\hline 1 & C,F & 8 & $25,81 \%$ & $8 / 14 \times 100 \%=57,14 \%$ \\
\hline 2 & F,C & 8 & $25,81 \%$ & $8 / 13 \times 100 \%=61,53 \%$ \\
\hline 3 & C,E & 7 & $22,58 \%$ & $7 / 14 \times 100 \%=50 \%$ \\
\hline 4 & E,C & 7 & $22,58 \%$ & $7 / 11 \times 100 \%=63,63 \%$ \\
\hline 5 & F,E & 10 & $32,26 \%$ & $10 / 13 \times 100 \%=76,92 \%$ \\
\hline 6 & E,F & 10 & $32,26 \%$ & $10 / 11 \times 100 \%=90,90 \%$ \\
\hline 7 & F, B & 9 & $29,03 \%$ & $9 / 13 \times 100 \%=69,23 \%$ \\
\hline 8 & B, F & 9 & $29,03 \%$ & $9 / 10 \times 100 \%=90 \%$ \\
\hline 9 & B,E & 8 & $25,81 \%$ & $8 / 10 \times 100 \%=80 \%$ \\
\hline 10 & E,B & 8 & $25,81 \%$ & $8 / 11 \times 100 \%=72,72 \%$ \\
\hline 11 & F,E,B & 8 & $25,81 \%$ & $8 / 10 \times 100 \%=80 \%$ \\
\hline 12 & F,B,E & 8 & $25,81 \%$ & $8 / 9 \times 100 \%=88,88 \%$ \\
\hline 13 & E,B,F & 8 & $25,81 \%$ & $8 / 8 \times 100 \%=100 \%$ \\
\hline 14 & E,F,B & 8 & $25,81 \%$ & $8 / 11 \times 100 \%=72,72 \%$ \\
\hline 15 & F, E,B & 8 & $25,81 \%$ & $8 / 13 \times 100 \%=61,53 \%$ \\
\hline 16 & B,F,E & 8 & $25,81 \%$ & $8 / 10 \times 100 \%=80 \%$ \\
\hline
\end{tabular}

Setelah mendapat itemset dengan nilai minimum support $20 \%$ dan minimum confidence $50 \%$, maka langkah selanjutnya dilakukan pembentukan association rule seperti pada Tabel 10 di bawah ini :

Tabel 10 Association Rule Dengan Nilai Minimum Support dan Minimum Confidence

\begin{tabular}{|c|c|c|l|l|}
\hline No & Itemset & Jumlah & Support \% & \multicolumn{1}{|c|}{ Confidence \% } \\
\hline 1 & C,F & 8 & $25,81 \%$ & $57,14 \%$ \\
\hline 2 & F, C & 8 & $25,81 \%$ & $61,53 \%$ \\
\hline 3 & C,E & 7 & $22,58 \%$ & $50 \%$ \\
\hline 4 & E,C & 7 & $22,58 \%$ & $63.63 \%$ \\
\hline 5 & F,E & 10 & $32,26 \%$ & $76,92 \%$ \\
\hline 6 & E,F & 10 & $32,26 \%$ & $90,90 \%$ \\
\hline 7 & F, B & 9 & $29,03 \%$ & $69,23 \%$ \\
\hline 8 & B, F & 9 & $29,03 \%$ & $90 \%$ \\
\hline 9 & B,E & 8 & $25,81 \%$ & $80 \%$ \\
\hline 10 & E,B & 8 & $25,81 \%$ & $72,72 \%$ \\
\hline 11 & F,E, B & 8 & $25,81 \%$ & $80 \%$ \\
\hline 12 & F,B,E & 8 & $25,81 \%$ & $88,88 \%$ \\
\hline 13 & E,B,F & 8 & $25,81 \%$ & $100 \%$ \\
\hline 14 & E,F,B & 8 & $25,81 \%$ & $72,72 \%$ \\
\hline 15 & F, E,B & 8 & $25,81 \%$ & $61,53 \%$ \\
\hline 16 & B,F,E & 8 & $25,81 \%$ & $80 \%$ \\
\hline
\end{tabular}


Setelah melakukan perhitungan nilai support dan nilai confidence, maka dapat diambil kesimpulan sebagai berikut :

Rule 1 : Jika menggunakan Asam Oxalate (C) maka akan menggunakan Natrium Sulfit (F) dengan support 25,81\% dan confidence $57,14 \%$.

Rule 2 : Jika menggunakan Natrium Sulfit (F) maka akan menggunakan Asam Oxalate (C) dengan support 25,81\% dan confidence $61,53 \%$.

Rule 3 : Jika menggunakan Asam Oxalate (C) maka akan menggunakan Natrium Disulfit (E) dengan support 22,58\% dan confidence $50 \%$.

Rule 4 : Jika menggunakan Natrium Disulfit (E) maka akan menggunakan Asam xalate (C) dengan support 22,58\% dan confidence $63,63 \%$.

Rule 5 : Jika menggunakan Natrium Sulfit (F) maka akan menggunakan Natrium Disulfit (E) dengan support 32,26\% dan confidence $76,92 \%$.

Rule 6 : Jika menggunakan Natrium Disulfit (E) maka akan menggunakan Natrium Sulfit (F) dengan support 32,26\% dan confidence 90,90\%.

Rule 7 : Jika menggunakan Natrium Sulfit (F) maka akan menggunakan 1- Amino - 2- hydroxynapthalin-4-sulfonsaure (B) dengan support $29,03 \%$ dan confidence $69,23 \%$.

Rule 8 : Jika menggunakan 1- Amino -2hydroxynapthalin-4-sulfonsaure (B) maka akan menggunakan Natrium Sulfit (F) dengan support $29,03 \%$ dan confidence $90 \%$.

Rule 9 : Jika menggunakan 1- Amino -2hydroxynapthalin-4-sulfonsaure (B) maka akan menggunakan Natrium Disulfit (E) dengan support $25,81 \%$ dan confidence $80 \%$.

Rule 10: Jika menggunakan Natrium Disulfit

(E) maka akan menggunakan 1- Amino -2- hydroxynapthalin-4-sulfonsaure (B) dengan support $25,81 \%$ dan confidence $72,72 \%$.

Rule 11 : Jika menggunakan Natrium Sulfit (F) dan Natrium Disulfit (E) maka akan menggunakan 1- Amino -2-hydroxynapthalin-4sulfonsaure (B) dengan support $25,81 \%$ dan confidence $80 \%$.

Rule 12: Jika menggunakan Natrium Sulfit (F) dan 1- Amino -2- hydroxynapthalin-4- sulfonsaure (B) maka akan menggunakan Natrium Disulfit (E) dengan support $25,81 \%$ dan confidence $88,88 \%$.

Rule 13: Jika menggunakan Natrium Disulfit (E) dan 1- Amino -2- hydroxynapthalin-

4-sulfonsaure (B) maka akan menggunakan Natrium Sulfit (F) dengan support 25,81\% dan confidence $100 \%$.

Rule 14: Jika menggunakan Natrium Disulfit (E) dan Natrium Sulfit (F) maka akan menggunakan 1Amino -2- hydroxynapthalin-4-sulfonsaure (B) dengan support $25,81 \%$ dan confidence $80 \%$.

Rule 15 : Jika menggunakan 1- Amino -2- hydroxynapthalin-4-sulfonsaure (B) dan Natrium Disulfit (E) maka akan menggunakan Natrium Sulfit (F) dengan support 25,81\% dan confidence 61, 53\%.

Rule 16 : Jika menggunakan 1- Amino -2- hydroxynapthalin-4-sulfonsaure (B) dan Natrium Sulfit (F) maka akan menggunakan Natrium Disulfit (E) dengan support 25,81\% dan confidence $80 \%$. 
ALGORITMA: Jurnal Ilmu Komputer dan Informatika

Volume: 03, Number: 02, November 2019 ISSN 2598-6341 (online)

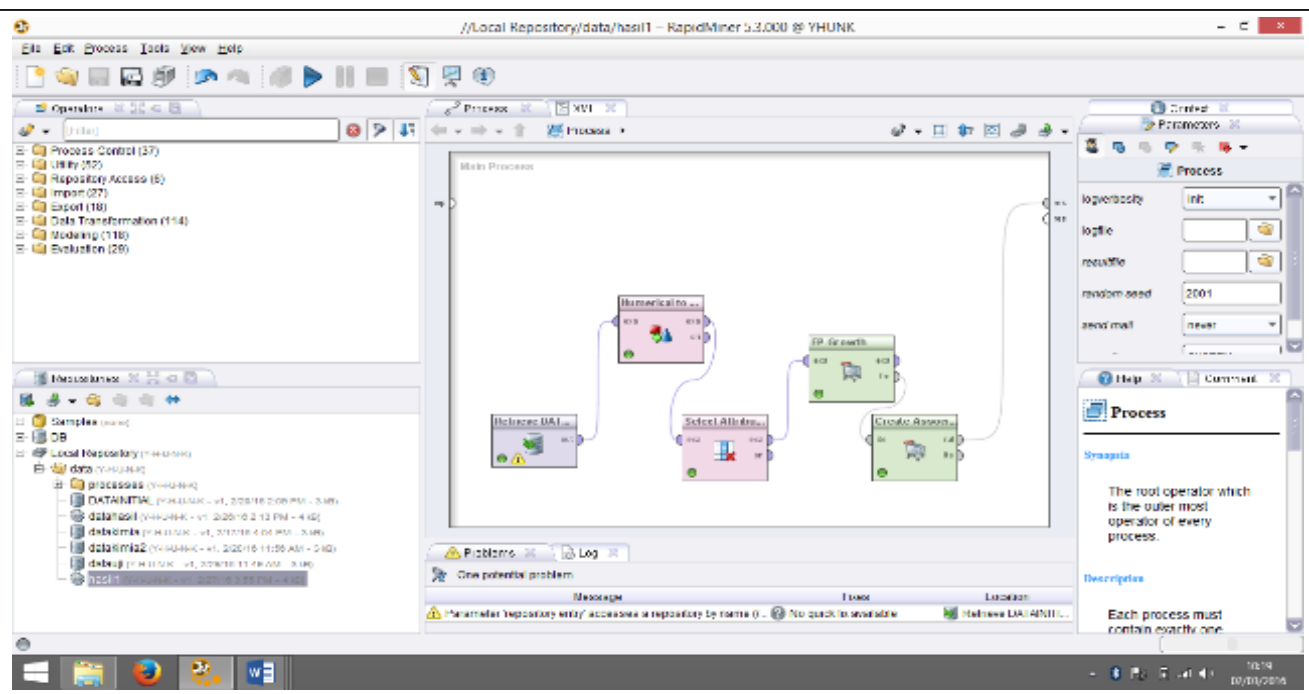

Gambar 8 Proses Menggunakan Aplikasi RapidMiner 5.3

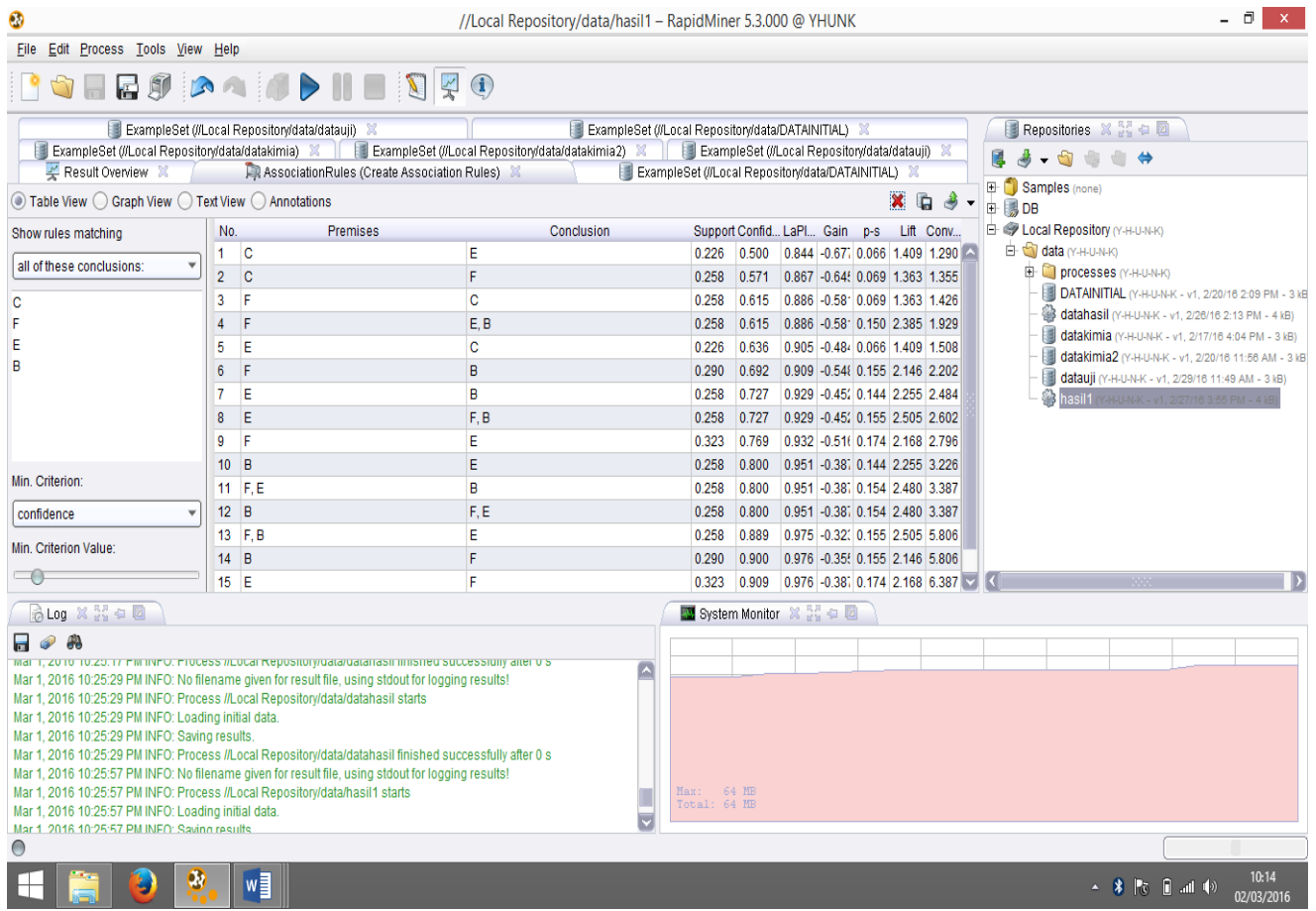

Gambar 9 Rule Dihasilkan Menggunakan Aplikasi RapidMiner 5.3

\section{Kesimpulan}

1. Metode dalam pencarian Frequent Itemsset pohon keputusan menggunakan algoritma FP-Growth bekerja sangat baik dalam melakukan Frequent Itemsset dengan proses pembentukan FP-Tree dengan menghasilkan rule dari data sampel pemakaian bahan kimia.

2. Penentuan data variabel sangat menentukan tingkat akurasi FP-Growth yang dibuat dan besarnya presentase dalam menentukan minum support dan minimum confidence dipengaruhi oleh data 
variabel yang digunakan untuk mencari frequent itemset yang saling berhubungan untuk menemukan variabel yang akan dijadikan acuan dalam pemakaian bahan kimia .

3. Dari penelitian yang dilakukan ada beberapa atribut yang tidak digunakan dalam rule yang dihasilkan, sehingga pemilihan atribut di dalam dataset sangat penting.

4. Algoritma FP-Growth dapat diterapkan untuk menganalisa pola pemakaian bahan kimia di laboratorium guna mempermudah sistem pengadaan maupun cara penyimpanannya.

\section{Referensi}

Software yang digunakan dalam pengujian ini adalah Microsoft Excel dan RapidMiner 5.3.

(Hermawati, 2009).

"Data Mining"

Rama Novta Miraldi, et al (2014).

“Implementasi Algoritma FP-GROWTH untuk Sistem Rekomendasi Buku di Perpustakaan UKDW”

Ririanti, (2014).

Implementasi algoritma fp-growth pada aplikasi Prediksi Persediaan Sepeda Motor (Studi Kasus PT. Pilar Deli Labumas) 